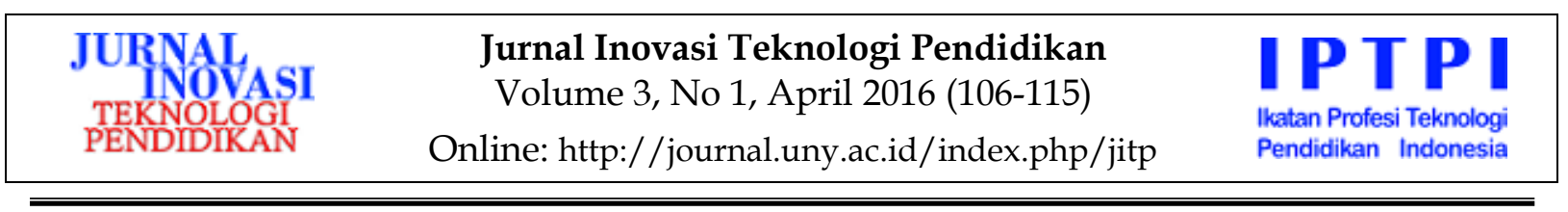

\title{
UPAYA MENINGKATKAN PEROLEHAN KOSAKATA DALAM PEMAHAMAN MEMBACA BAHASA INGGRIS MENGGUNAKAN VSS PADA SISWA SMP
}

\author{
Windarti ${ }^{1}$ C. Asri Budiningsih ${ }^{2}$ \\ Teknologi Pembelajaran PPs UNY1, FIP Universitas Negeri Yogyakarta ${ }^{2}$ \\ windarti5606@gmail.com, asri_budi@yahoo.co.id
}

\begin{abstract}
Abstrak
Penelitian ini bertujuan untuk meningkatkan perolehan kosakata dalam pemahaman membaca bahasa Inggris menggunakan Vocabulary Self-Collection Strategy (VSS) siswa kelas VII SMP Negeri 3 Kalasan. Metode penelitian yang digunakan yaitu penelitian tindakan kelas (PTK), yang terdiri dari dua siklus. Tiap siklus terdiri dari empat tahap, yaitu perencanaan, pelaksanaan, pengamatan, dan refleksi. Subjek penelitian ini adalah 32 siswa kelas VII B SMP Negeri 3 Kalasan tahun ajaran 2013/2014. Teknik pengumpulan data yang digunakan yaitu observasi, tes, dan wawancara. Analisis data yang digunakan yaitu deskriptif kuantitatif dan deskriptif kualitatif. Hasil penelitian ini menunjukan bahwa penerapan strategi VSS dapat digunakan untuk meningkatkan perolehan kosakata dalam pemahaman membaca bahasa Inggris. Peningkatan hasil belajar siswa ditunjukkan dengan meningkatnya jumlah siswa yang lulus standar KKM pada siklus I dan II. Nilai rata-rata tes pada siklus I adalah 77,2. Nilai rata-rata tes pada siklus II adalah 82,4. Kesimpulan pada penelitian ini adalah bahwa penerapan strategi VSS dapat meningkatkan perolehan kosakata bahasa Inggris dalam pemahaman membaca siswa kelas VII SMP Negeri 3 Kalasan.

Kata kunci: VSS, perolehan kosakata, pemahaman membaca bahasa Inggris.
\end{abstract}

\section{THE EFFORT TO IMPROVE VOCABULARY ACQUISITION IN ENGLISH READING COMPREHENSION USING VSS ON THE STUDENTS OF SMP}

\author{
Windarti ${ }^{1}, \mathrm{C}$. Asri Budiningsih ${ }^{2}$ \\ Teknologi Pembelajaran PPs UNY11, FIP Universitas Negeri Yogyakarta² \\ windarti5606@gmail.com, asri_budi@yahoo.co.id
}

\begin{abstract}
This study aims to improve vocabulary acquisition in English reading comprehension using Vocabulary Self-Collection Strategy (VSS) on the seventh grade students of SMP Negeri 3 Kalasan. This was an action reserch study consisting of two cycles. Each cycle consisted of four steps, namely planning, implementation, observation, and reflection. The research subjects were 32 seventh grade students of SMP 3 Kalasan in the academic year of 2013/2014. The data were collected through observation, tests, and interviews and analyzed by means of quantitative and qualitative descriptive techniques. The result shows that VSS could be used to improve vocabulary acquisition in English reading comprehension. The increase of students' learning achievement was shown through the increasing number of students who passed the KKM in cycle I and II. The avarage test score in cycle I was 77.2. The average test scores in cycle II was 82.4. The conclusion of this research is that the implementation of VSS could improve the vocabulary acquisition in English reading comprehension on the seventh grade students of SMP Negeri 3 Kalasan.
\end{abstract}

Keywords: VSS, vocabulary acquisition, English reading comprehension. 



\section{Pendahuluan}

Bahasa Inggris merupakan bahasa Internasional yang digunakan masyarakat dunia sebagai alat komunikasi secara lisan dan tulis. Bahasa Inggris adalah salah satu bahasa yang digunakan secara luas dalam berbagai aspek kehidupan manusia yang memiliki peran vital dalam perkembangan intelektual, sosial budaya, ekonomi dan pendidikan. Keputusan pemerintah menetapkan bahasa Inggris sebagai salah satu mata pelajaran di berbagai jenjang pendidikan sangat beralasan demi mempersiapkan generasi Indonesia untuk bersaing secara global. Pendidikan bahasa Inggris diajarkan pada tiap jenjang pendidikan di Indonesia. Sekolah-sekolah dasar, menengah, hingga perguruan tinggi, memasukkan mata pelajaran bahasa Inggris sebagai salah satu program unggulan.

Mengingat kurikulum 2013 yang bertujuan untuk mempersiapkan manusia Indonesia agar memiliki kemampuan hidup sebagai pribadi dan warga negara yang beriman, produktif, kreatif, inovatif dan afektif serta mampu berkontribusi pada kehidupan bermasyarakat, berbangsa, bernegara, dan peradaban maka di butuhkan upaya mempersiapkan generasi masa depan yang tangguh, cerdas, mandiri dan berpegang teguh pada nilai-nilai spritual.

Kurikulum 2013 menekankan pada pendekatan ilmiah (scientific approach) dengan model pembelajaran berbasis masalah (problem-based learning), pembelajaran berbasis penemuan (discovery learning), dan pembelajaran berbasis proyek (project-based learning). Model pembelajaran tersebut memberi peluang guru untuk lebih kreatif dan inovatif dalam mengembangkan model pembelajaran serta mengajak siswa untuk aktif menggunakan berbagi sumber belajar.

Secara garis besar, materi pembelajaran bahasa Inggris ditekankan pada kompetensi berbahasa sebagai alat komunikasi untuk menyampaikan gagasan dan pengetahuan. Menurut Nawab (2012, p. 696) teaching English is not merely transmitt- ing information to the learners rather it is to enable them speak, read and write fluently. Dari pernyataan tersebut, dapat disimpulkan bahwa pembelajaran bahasa Inggris tidak hanya menyampaikan informasi kepada siswa melainkan juga untuk berbicara, membaca dan menulis secara lancar. Pembelajaran Bahasa Inggris pada jenjang SMP/MTs ditargetkan agar siswa dapat mencapai tingkat literasi fungsional, yakni berkomunikasi secara lisan dan tulis untuk menyelesaikan masalah sehari-hari. Dengan mencapai tingkat literasi fungsional, berarti siswa telah mampu memahami dan mengungkapkan informasi, pikiran, perasaan, serta mengembangkan ilmu pengetahuan, teknologi dan budaya (BSNP, 2006, p.277).

Tujuan pembelajaran bahasa Inggris agar siswa mendapatkan pengetahuan serta keterampilan dalam berbahasa serta mampu mewujudkan generasi muda yang mampu bersaing secara global. Dalam pembelajaran Bahasa Inggris terdapat empat keterampilan yang harus dikuasai oleh siswa, yaitu: keterampilan menyimak (listening), membaca (reading), menulis (writing) dan berbicara (speaking). Keempat keterampilan tersebut digunakan untuk menciptakan wacana dalam kehidupan bermasyarakat. Oleh karena itu dalam pembelajaran Bahasa Inggris, siswa diarahkan untuk mengembangkan keterampilan tesebut. Dengan menguasai empat keterampilan dalam berbahasa maka siswa mampu berkomunikasi dan berwacana dalam Bahasa Inggris pada tingkat literasi tertentu.

Penguasaan materi pelajaran bahasa Inggris meliputi keterampilan reseptif dan produktif. Keterampilan reseptif meliputi keterampilan menyimak dan membaca, sedangkan keterampilan produktif meliputi keterampilan berbicara dan menulis. Baik keterampilan reseptif maupun produktif, siswa perlu mengembangkan keterampilan tersebut dalam proses pembelajaran. Agar dapat menguasai keterampilan reseptif dan produktif, siswa perlu dibekali unsur-unsur bahasa lainnya, mi- 
salnya tata bahasa, tata tulis, tata bunyi, sistem makna dan kosa kata.

Kosa kata (vocabulary) adalah hal mendasar yang perlu dikuasai oleh siswa dalam pembelajaran, tanpa penguasaan kosa kata yang cukup siswa akan kesulitan dalam berkomunikasi. Menurut Linse (2005, p. 121) vocabulary is collection of words that an individual knows. Kosakata adalah kumpulan dari kata-kata agar seseorang itu mengerti. Kosakata sangat perlu diajarkan kepada siswa untuk menunjang keterampilan bahasa Inggris. Penguasaan kosakata memiliki hubungan yang erat dengan empat keterampilan dalam berbahasa (reading, writing, speaking, listening). Tanpa penguasaan kosakata, siswa akan terhambat dalam keterampilan reading, writing, speaking dan listening. Penguasaan kosakata yang kurang optimal, siswa akan mengalami kesulitan memahami bacaan bahasa Inggris dan mengerti makna yang terkandung di dalamnya, sehingga sulit dalam menjawab pertanyaan yang diberikan guru. Begitu juga dengan berbicara, siswa akan terhambat dalam percakapan meskipun siswa telah menyimak dengan baik apa yang diutarakan siswa yang lain.

Berkaitan dengan peraturan pemerintah tentang Standar Nasional Pendidikan bab IV pasal 19 ayat 1 mengatakan bahwa 'proses pembelajaran pada satuan pendidikan diselenggarakan secara interaktif, inspiratif, menyenangkan, menantang, memotivasi siswa untuk berpartisipasi aktif, dan memberikan ruang yang cukup bagi prakarsa, kreativitas, dan kemandirian sesuai dengan bakat, minat, dan perkembangan fisik serta psikologis siswa. Dari pernyataan tersebut, strategi pembelajaran merupakan aspek penting dalam proses belajar mengajar. Dibutuhkan strategi pembelajaran yang menunjang agar terselenggaranya pembelajaran secara interaktif, menyenangkan, dan memotivasi siswa untuk berpartisipasi aktif. Banyak strategi pembelajaran yang dikembang oleh para ahli bahasa dalam pembelajaran bahasa Inggris sebagai bahasa asing, na- mun tidak semua strategi atau teknik pengajaran yang cocok dalam pembelajaran.

Di dalam proses pembelajaran, diharapkan guru memiliki strategi belajar sebagai pola-pola umum kegiatan guru dan siswa dalam mewujudkan kegiatan belajar mengajar untuk mencapai tujuan pembelajaran. Strategi belajar menurut Nunan, (Hardini dan Puspitasari, 2011, p. 12) meliputi rencana, metode, dan perangkat kegiatan yang direncanakan untuk mencapai tujuan tertentu. Metode pembelajaran merupakan cara yang ditempuh guru untuk menciptakan situasi pembelajaran yang menyenangkan dan mendukung bagi kelancaran proses belajar. Oleh karena itu agar siswa mencapai tujuan dalam proses belajar mengajar, pemilihan strategi atau teknik sangat penting diperhatikan. Jika seorang guru belum tepat dalam mempersiapkan hal tersebut, maka tujuan pembelajaran tidak dapat tercapai. Kasus seperti ini terjadi pada kelas VII SMP Negeri 3 Kalasan.

Dari hasil mengamati dan wawancara dengan guru bahasa Inggris kelas VII SMP Negeri 3 Kalasan pada tanggal 21 Juli 2014, peneliti menemukan fakta sebagai berikut: pertama, pemahaman bacaan berbahasa Inggris siswa masih kurang dari harapan. Kendala yang dihadapi yaitu minimnya kesadaran siswa untuk melakukan aktivitas membaca serta rendahnya penguasaan kosakata berbahasa Inggris yang dapat mempengaruhi pemahaman bacaan berbahasa Inggris. Rendahnya penguasaan kosakata yang dimiliki siswa, menyebabkan terhambatnya pembelajaran bahasa Inggris. Siswa kurang memahami penjelasan yang disampaikan oleh guru, siswa kesulitan dalam menjawab pertanyaan dengan baik secara lisan maupun tulis. Kedua, hanya sebagian kecil dari siswa memliki perbendaharaan kosakata bahasa Inggris yang diatas rata-rata. Ketiga, strategi pembelajaran yang digunakan guru sudah tidak efektif lagi, dapat diidentifikasi saat sebagian siswa acuh tak acuh dalam mendengarkan penjelasan guru. 
Dalam rangka mengatasi persoalan rendahnya pemahaman membaca, diperlukan upaya meningkatkan kemampuan siswa dalam perolehan kosakata serta kemampuan pemahaman membaca siswa khususnya bidang bahasa Inggris. Salah satu upaya yang dapat dilakukan adalah dengan meningkatkan kualitas pembelajaran dengan penerapan strategi pembelajaran yang tepat. Strategi pembelajaran yang tepat adalah strategi yang berpusat pada keaktifan siswa.

Strategi pembelajaran merupakan kunci peningkatan jaminan kualitas pembelajaran. Hal ini dikarenakan strategi pembelajaran memuat berbagai rencana tindakan yang didesain untuk mencapai tujuan pendidikan tertentu dengan memanfaatkan berbagai sumber daya/kekuatan dalam pembelajaran (Sanjaya, 2008, p. 126). Stategi pembelajaran selalu bersinambung dengan hasil belajar siswa siswa, dengan begitu pemilihan stategi pembelajaran harus tepat dan efektif.

Strategi VSS merupakan strategi yang sesuai dengan kurikulum 2013 yaitu strategi pembelajaran yang berpusat pada siswa (student centered learning).

Menurut Haggard (1982, p. 203), "the vocabulary self-collection or VSS, is a fundamental way of opening students minds to the wealth of words they encounter in print and the oral language that surrounds them each day:raising word consciousness". Stategi VSS salah satu alternatif strategi pembelajaran yang mengajak siswa aktif dalam proses belajar. Dalam strategi ini, siswa diberi kepercayaan untuk mencari makna kosakata yang sulit yang mereka anggap penting dan menarik untuk dipelajari berdasarkan topik yang telah diberikan guru di akhir pelajaran sebelumnya. Pada pertemuan berikutnya, salah satu siswa dari kelompoknya mempresentasikan apa arti kata tersebut menurut mereka dan alasan mengapa siswa harus mempelajarinya. Dalam diskusi ini, dilakukan penyisihan kosakata yang muncul lebih dari satu kali dan kosakata yang familiar. Kosakata yang terpilih akan masuk ke dalam daftar kosakata pribadi mereka. Peran guru adalah memantau proses belajar dan menilai hasil kerja serta mendiskusikannya.

Masalah rendahnya penguasaan kosakata yang dihadapi oleh siswa SMP Negeri 3 Kalasan tersebut merupakan masalah yang penting untuk diatasi. Hal ini memotivasi peneliti untuk melakukan penelitian tindakan kelas pada siswa SMP Negeri 3 Kalasan. Peneliti dan guru berdiskusi bersama mengenai VSS adalah solusi yang tepat untuk memecahkan masalah yang dihadapi. Peneliti dan guru memilih strategi VSS karena strategi tersebut merangkap semua proses pembelajaran bahasa Inggris baik secara lisan maupun tulis. Penelitian tentang strategi pembelajaran termasuk dalam kawasan desain dalam teknologi pembelajaran.

\section{Metode Penelitian}

Jenis penelitian yang dilakukan dalam penelitian ini adalah penelitian tindakan kelas (PTK), yang bertujuan untuk meningkatkan perolehan kosakata dalam pemahaman membaca bahasa Inggris menggunakan strategi VSS pada siswa SMP Negeri 3 Kalasan.

Penelitian dilakukan di SMP Negeri 3 Kalasan. Penelitian dimulai pada bulan September hingga Oktober 2014. Subjek penelitian ini adalah siswa SMP Negeri 3 Kalasan kelas VII B sebanyak 32 siswa.

Desain penelitian ini mengikuti model penelitian tindakan kelas menurut Kemmis dan Taggart (1988) yang dilaksanakan dalam 2 siklus. Alur pelaksanaan tindakan dirancang sebagai berikut: perencanaan, pelaksanaan, pengamatan dan refleksi.

Data yang dibutuhkan dalam penelitian ini yaitu data tentang pelaksanaan pembelajaran. Instrumen dan teknik yang digunakan yaitu observasi, tes dan wawancara.

Teknik analisis data dalam penelitian ini adalah analisis deskriptif. Ada dua jenis data dalam penelitian tindakan ini yaitu kualitatif dan kuantitatif. Data 
kualitatif berupa informasi hasil wawancara dan pengamatan untuk mengetahui peningkatan pembelajaran bahasa Inggris menggunakan strategi VSS. Analisis data kualitatif dilakukan dengan mengadopsi model analisis Miles dan Hubberman (1984, p. 21). Analisis interaktif tersebut terdiri dari tiga komponen kegiatan yang saling berkaitan satu sama lain, yaitu: reduksi data, penyajian data dan penarikan kesimpulan. Data kuantitatif berupa nilai tes kosakata bahasa Inggris dan hasil cek list pengamatan pelaksanaan strategi pembelajaran VSS. Pengamatan penerapan strategi VSS menggunakan skala penilaian dengan rentang nilai dalam bentuk angka $(4,3,2,1)$ yang berarti skor 4 sangat baik (SB), skor 3 baik (b), skor 2 kurang (K), skor 1 sangat kurang (SK).

Tabel 1. Kualifikasi Perolehan Skor Total Pengamatan Penerapan VSS

\begin{tabular}{cc}
\hline Jumlah Skor & Kategori \\
& \\
\hline $61.74 \leq \times \leq 76$ & Sangat Baik \\
$47.4 \leq \times \leq 61.75$ & Baik \\
$33.24 \leq \times \leq 47.5$ & Kurang \\
$19 \leq \times \leq 33.25$ & Sangat Kurang \\
\hline
\end{tabular}

\section{Hasil Penelitian dan Pembahasan}

Penelitian tindakan kelas dilaksanakan dalam 2 siklus. Alur pelaksanaan tindakan dirancang sebagai berikut: Perencanaan, pelaksanaan, pengamatan dan refleksi.

\section{Perencanaan Tindakan}

Pada tahap perencanaan guru dan peneliti mengidentifikasi masalah yang dihadapi oleh siswa dalam proses pembelajaran bahasa Inggris di SMP Negeri 3 Kalasan. Berdasarkan hasil identifikasi masalah, bahwasanya salah satu sebab menghambatnya proses pembelajaran bahasa Inggris adalah kurangnya perolehan kosakata bahasa Inggris.

Langkah kedua adalah merancang pemecahan masalah. Rancangan pemecah- annya berupa langkah-langkah yang dilakukan untuk memecahkan permasalahan yang telah dihadapi guru dan siswa. Langkah yang dilakukan adalah dengan menerapkan pembelajaran kosakata dengan menggunakan VSS. Langkah berikutnya guru dan peneliti menyiapkan instrumen observasi dan instrumen tes yang digunakan untuk mengamati proses tindakan.

\section{Pelaksanaan Tindakan}

Pada tahap pelaksanaan tindakan, rencana tindakan diimplementasikan di kelas yang nyata. Proses pembelajaran berlangsung di kelas dan pada jam mengajar yang sesuai dengan jadwal pelajaran yang berlaku di kelas VII B SMP Negeri 3 Kalasan. Guru bersama peneliti menerapkan pembelajaran bahasa Inggris menggunakan VSS pada setiap pertemuan.

Berdasarkan hasil penelitian, VSS berhasil diterapkan dalam mata pelajaran bahasa Inggris dengan kategori baik pada siklus I dan kategori sangat baik pada siklus II. Pada siklus I langkah pembelajaran belum mencapai kriteria keberhasilan yaitu strategi dan lingkungan. Sedangkan langkah yang telah mencapai kriteria keberhasilan yaitu sumber belajar dan peserta didik. Pada siklus II terjadi peningkatan proses pembelajaran sehingga seluruh langkah pembelajaran mengalami peningkatan dan mencapai kriteria keberhasilan.

Pelaksanaan berlangsung sesuai dengan langkah-langkah VSS sebagai berikut: (1) siswa diperkenalkan strategi VSS, tujuan pembelajaran dan proses pembelajaran, (2) terbentuknya kelompok belajar, siswa bekerja sama dalam kelompok kecil, (3) siswa diberikan contoh bagaimana memilih kata-kata penting dari bacaan dan menunjukan mengapa kata tersebut penting untuk dipilih, (4) setiap kelompok menyajikan dua kata serta memberikan makna dan alasan memilih kata tersebut dipilih dan kalimat di mana kata ini digunakan. Dalam diskusi, siswa mengeliminasi kata yang sudah digunakan oleh kelompok lainnya, (5) dari hasil temuan kosa- 
kata siswa mempresentasikan pada teman sekelasnya kata temuannya, sumber kata yang didapat, menentukan arti kata yang didapat dan mengapa menurut siswa kata tersebut penting untuk dipelajari, (6) langkah terakhir adalah siswa menentukan nominasi kata yang akan dipelajari.

Dari hasil wawancara, pelaksanaan pembelajaran yang dilakukan cenderung fleksibel karena dari segi tempat, waktu, bahan belajar, dan aktivitas pembelajaran yang dilakukan tidak monoton. Siswa terlihat antusias dalam pengajaran kosakata. Berdasarkan hal ini peneliti menyimpulkan bahwasanya strategi pembelajaran kosakata menggunakan strategi VSS dapat meningkatkan motivasi siswa dalam perolehan kosakata. Siswa diberi kepercayaan untuk memilih kosakata sendiri sehingga siswa lebih mandiri dalam mempelajari kosakata.

Pengamatan Tindakan

Pada tahap pengamatan tindakan, peneliti menggunakan lembar observasi yang telah disusun untuk mengetahui kesesuaian langkah-langkah yang direncanakan dengan penerapan di dalam kelas. Pengamatan berikutnya adalah memberikan tes pada setiap siklus untuk mengetahui perolehan kosakata dan pemahaman membaca siswa. Kemudian melakukan wawancara kepada siswa mengenai pelaksanaan pembelajaran menggunakan strategi VSS.

Berdasarkan hasil pengamatan tindakan VSS siklus II dihasilkan data sebagaimana disajikan pada Tabel 2.

Tabel 2. Hasil Pengamatan Penerapan VSS Siklus I

\begin{tabular}{clcc}
\hline No & Kompenen & Skor & Kategori \\
\hline 1 & Pendidik & 9 & Baik \\
2 & Peserta didik & 10 & Baik \\
3 & Sumber belajar & 12 & Baik \\
4 & Lingkungan & 4 & Kurang \\
5 & Strategis & 13 & Kurang \\
\hline Skor & Total & 48 & Baik \\
\hline
\end{tabular}

Selain pengamatan terhadap proses pembelajaran pengamatan juga dilakukan terhadap hasil belajar siswa. Secara umum, hasil tes hasil belajar siswa pada siklus I menunjukan adanya peningkatan. Pada tes hasil belajar siswa setelah diberi tindakan, jumlah siswa yang lulus standar nilai KKM meningkat. Jumlah siswa yang lulus standar KKM pada saat sebelum diberi tindakan yaitu 17 siswa atau 53,1\% dari jumlah seluruh anak, sementara jumlah yang lulus standar KKM setelah diberi tindakan yaitu 22 atau $68,7 \%$. Hasil belajar siswa meningkat $15,6 \%$.

Berdasarkan hasil tes belajar siswa pada siklus I diketahui rata-rata nilai tes yang diperoleh adalah 77,2 , dengan nilai terendah 69,6 dan nilai tertinggi 96,9. Gambar diagram batang berikut ini menunjukkan lebih jelas peningkatan hasil belajar siswa setelah diberi tindakan.

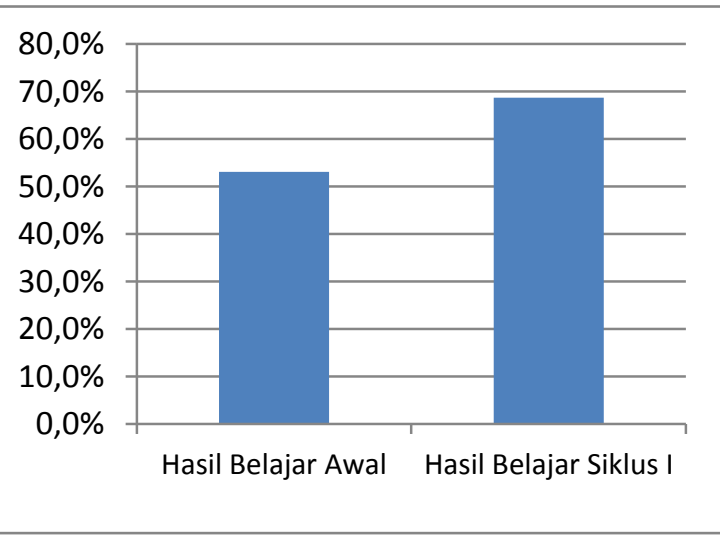

Gambar 1. Diagram Batang Hasil Tes Hasil Belajar Siswa Siklus I

Berdasarkan hasil pengamatan tindakan penerapan VSS siklus II dihasilkan data sebagaimana disajikan Tabel 3 .

Tabel 3. Hasil pengamatan Penerapan VSS Siklus II

\begin{tabular}{llll}
\hline No & Kompenen & Skor & Kategori \\
\hline 1 & Pendidik & 9 & Baik \\
2 & Peserta didik & 13 & Baik \\
3 & Sumber belajar & 12 & Baik \\
4 & Lingkungan & 6 & Baik \\
5 & Strategis & 19 & Baik \\
\hline Skor Total & 59 & Baik \\
\hline
\end{tabular}


Pada Tabel 3 dapat dilihat bahwa pengamatan penerapan strategi VSS yang terdiri dari 5 komponen yang diamati, masuk dalam kategori baik. Skor total 59 berdasarkan hasil pengamatan siklus II menyatakan bahwa penerapan strategi VSS berada pada kategori baik.

Selain pengamatan terhadap proses pembelajaran pengamatan juga dilakukan terhadap hasil belajar siswa pada siklus II. Berdasarkan hasil tes pada siklus II diketahui bahwa rata-rata nilai tes yang diperoleh siswa 82,4. Siswa yang mencapai KKM sebanyak 28 orang atau $87,5 \%$. Hal ini berarti, setelah diberi tindakan hasil belajar siswa mengalami peningkatan sebesar $18,8 \%$. Hasil perolehan nilai tes pada siklus II terendah 71,4 dan tertinggi 91,4. Gambar diagram batang berikut menunjukkan lebih jelas peningkatan hasil belajar siswa setelah diberi tindakan.

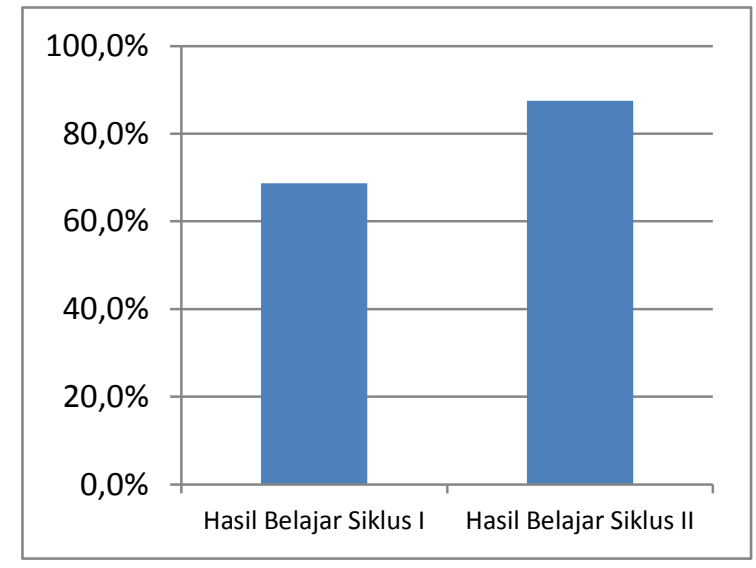

Gambar 2. Diagram Batang Hasil Tes Hasil Belajar Siswa Siklus II

Refleksi Tindakan

Pada tahap refleksi tindakan, peneliti mengevaluasi tindakan yang telah dilaksanakan selama proses pembelajaran bahasa Inggris menggunakan VSS. Hasil analisis kemudian digunakan untuk merencanakan kegiatan pada siklus selanjutnya. Berdasarkan tindakan yang telah dilakukan pada siklus I, peneliti dan guru berdiskusi mengenai refleksi pembelajaran yang telah dilakukan. Menurut peneliti dan guru, selama pelaksanaan strategi VSS pada siklus I muncul beberapa permasalahan dasar diantaranya: Pertama, alokasi waktu. Guru dan siswa belum mengoptimalkan waktu dengan baik walaupun dalam pelaksanaanya sering terjadi insiden diluar waktu perencanaan awal, seperti: (1) guru masih sibuk menyimpulkan materi pelajaran sedangkan bel berbunyi, tanda jam pelajaran berakhir; (2) siswa masih sering gaduh dalam menominasi kata perkelompok; (3) beberapa siswa masih banyak yang tidak membawa kamus untuk mendukung perolehan kosakata

Kedua, penguasaan kelas. Penguasaan kelas adalah bagian dari pembelajaran. Guru perlu menguasai suasana kelas pada saat penerapan strategi VSS. Suasana kelas menjadi gaduh saat siswa yang tergabung dalam kelompok adalah pilihan siswa. Pembagian kelompok tidak bervariasi, siswa cenderung memilih teman kelompok dengan teman sebangku atau teman dibelakangnya.

Ketiga adalah penerapan strategi VSS. Pada siklus I penerapan strategi VSS belum berjalan secara optimal. Siswa cenderung kurang percaya diri dalam menyampaikan hasil kerja kelompok di depan kelas. Hal ini menunjukan bahwa siswa belum terbiasa menggunakan strategi baru yang diterapkan.

Berdasarkan permasalahan tersebut, ada beberapa tindakan yang diperbaiki pada siklus I pertama adalah alokasi waktu, yaitu: (1) guru menggunakan waktu secara optimal dengan mengalokasikan waktu untuk masing-masing kegiatan sehingga kegiatan akan berjalan lebih terarah atau terstruktur; (2) setiap anggota kelompok harus memberikan ide dalam menominasi kata; (3) guru memberikan motivasi siswa dengan memberi feedback dan bimbingan, (4) guru memberikan pemahaman kembali langkah-langkah strategi pembelajaran VSS.

Permasalahan kedua adalah penguasaan kelas. Guru mengubah penataan duduk siswa dengan mengoptilmalkan ruangan menjadi letter U. Hal ini diharapkan agar guru dapat memantau kegiatan siswa 
dengan baik. Dari hasil refleksi di atas peneliti masih perlu melakukan tindakan lanjutan untuk memperbaiki kekurangan yang terdapat pada siklus I. Hal ini dilakukan untuk meningkatkan dan memaksimalkan perolehan kosakata serta pemahaman dalam membaca teks bahasa Inggris. Tindakan pada siklus II merupakan modifikasi rancangan pembelajaran pada siklus I dengan mengacu pada hasil refleksi siklus I.

Berdasarkan tindakan yang telah dilakukan pada siklus II, peneliti dan guru berdiskusi mengenai refleksi pembelajaran yang telah dilakukan. Menurut peneliti dan guru, hasil refleksi yang dilakukan pada siklus II menunjukan bahwa penerapan strategi VSS dalam pembelajaran bahasa Inggris untuk kelas VII B SMP Negeri Kalasan meningkat. Terjadinya peningkatan dalam memperoleh kosakata bahasa Inggris dapat dilihat dari perbedaan peningkatan skor rata-rata pretes, siklus I dan siklus II. Pada kegiatan pembelajaran, siswa merasa senang, bersemangat, dan termotivasi untuk belajar bahasa Inggris karna diberi kesempatan untuk mencari kosakata yang ingin mereka pelajari. Menurut siswa, hal ini mempermudah mereka mengingat kosakata dan memahami teks bacaan bahasa Inggris.

Pada siklus II, guru memberikan pemahaman kembali langkah-langkah strategi pembelajaran VSS sehingga siswa tidak lagi ragu dengan apa yang dikerjakannya. Guru menggunakan waktu secara optimal dengan mengalokasikan waktu untuk masing-masing kegiatan, sehingga kegiatan akan berjalan lebih terarah atau terstruktur. Guru mengalokasikan kegiatan pre-activity \pm 15 menit, kegiatan inti \pm 60 menit dan kegiatan penutup \pm 15 menit.

Berdasarkan hasil pengamatan dan wawancara yang dilakukan oleh peneliti selama tindakan siklus II terhadap subyek, proses pembelajaran berjalan secara efektif dan efisien, pembelajaran berlangsung menyenangkan dan memotivasi siswa dalam memperoleh kosakata bahasa Inggris. Berdasarkan hasil analisis, peneliti dan guru merasa kegiatan pembelajaran dengan strategi VSS sudah cukup dan tidak perlu dilakukan tindakan lanjut karna sudah ada peningkatan dalam memperoleh kosakata bahasa Inggris.

Berdasarkan hasil penelitian yang telah dilakukan pada siswa SMP Negeri 3 Kalasan, kelas VII B bahwasanya hasil penelitian ini sesuai dengan teori Rudell dan Shearer (Harmon, Wood \& Kiser, 2009, p. 59) bahwasanya Rudell dan Shearer menggunakan VSS kepada siswa kelas VII dan VIII mencapai hasil yang positif untuk membantu siswa menjadi lebih mandiri dalam mempelajari kosakata baru. Harmon, Wood \& Kiser menambahkan bahwasanya Fisher, Blachowicz, dan Smith juga pernah melakukan penelitian terhadap siswa yang memilih kosakata sendiri, dalam konteks pembelajaran kooperatif. Hasil penelitian mereka menunjukan bahwa siswa dapat termotivasi untuk lebih mandiri dalam pembelajaran kata.

Langkah-langkah penerapan VSS yang digunakan guru sesuai dengan langkah-langkah yang telah diterapkan oleh Rudell dan Shearer (Yopp, Yopp \& Bishop, 2009, p. 139) yaitu, guru mengenalkan strategi VSS kepada siswa agar siswa mengetahui dan dapat membedakan strategi VSS dengan strategi yang lain. Kemudian guru meminta siswa untuk mencari dua kosakata yang berhubungan dengan pelajaran yang mereka anggap penting untuk dipelajari lewat bahan bacaan dari berbagai sumber misalnya, koran, majalah, televisi, dan diskusi kelas. Dari hasil temuan kosakata, siswa mempresentasikan pada teman sekelasnya. Dalam proses nominasi, siswa mempresentasikan setiap kata temuannya, sumber kata yang didapat, menentukan arti kata yang didapat, dan mengapa menurut siswa kata tersebut penting untuk dipelajari. Setelah mendengarkan hasil kosakata yang telah siswa presentasikan, para siswa menvoting kosakata yang penting untuk mereka pelajari.

Berdasarkan hal ini peneliti menyimpulkan bahwasanya strategi pembelajaran kosakata menggunakan strategi VSS 
dapat meningkatkan motivasi siswa dalam perolehan kosakata. Siswa diberi kepercayaan untuk memilih kosakata sendiri sehingga siswa lebih mandiri dalam mempelajari kosakata.

Hasil penelitian ini sesuai dengan teori Rudell dan Shearer (Harmon, Wood \& Kiser, 2009, p. 59) bahwasanya Rudell dan Shearer menggunakan strategi VSS (Vocabulary Self-Collection Strategy) kepada siswa kelas VII dan VIII mencapai hasil yang positif untuk membantu siswa menjadi lebih mandiri dalam mempelajari kosakata baru. Harmon, Wood \& Kiser menambahkan bahwasanya Fisher, Blachowicz, dan Smith juga pernah melakukan penelitian terhadap siswa yang memilih kosakata sendiri, dalam konteks pembelajaran kooperatif. Hasil penelitian mereka menunjukkan bahwa siswa dapat termotivasi untuk lebih mandiri dalam pembelajaran kata.

Dengan meningkatnya perolehan kosakata bahasa Inggris akan memudahkan siswa dalam memahami bacaan berbahasa Inggris. Hal ini senada dengan pernyataan Munkova (2014, p. 199) bahwa membaca merupakan suatu keterampilan yang memiliki beberapa aspek pendukung, diantaranya penguasaan kosakata dan kemampuan memahami atau menyimpulkan kata-kata dalam bacaan.

\section{Simpulan dan Saran}

\section{Simpulan}

Hasil penelitian tindakan kelas yang telah dilakukan di kelas VII B di SMP Negeri 3 Kalasan dengan menggunakan strategi VSS) dapat digunakan untuk meningkatkan perolehan kosakata dalam pemahaman bacaan bahasa Inggris. Penerapan strategi VSS dilakukan melalui langkahlangkah berikut (1) siswa diperkenalkan VSS, tujuan pembelajaran dan proses pembelajaran, (2) terbentuknya kelompok belajar, siswa bekerja sama dalam kelompok kecil, (3) siswa diberikan contoh bagaimana memilih kata-kata penting dari bacaan dan menunjukan mengapa kata tersebut penting untuk dipilih, (4) setiap kelompok menyajikan dua kata serta memberikan makna dan alasan memilih kata tersebut dipilih dan kalimat di mana kata ini digunakan. Dalam diskusi, siswa mengeliminasi kata yang sudah digunakan oleh kelompok lainnya, (5) dari hasil temuan kosakata siswa mempresentasikan pada teman sekelasnya kata temuannya, sumber kata yang didapat, menentukan arti kata yang didapat dan mengapa menurut siswa kata tersebut penting untuk dipelajari (6) langkah terakhir adalah siswa menentukan nominasi kata yang akan dipelajari.

Peningkatan hasil belajar siswa ditunjukan dengan penambahan jumlah yang lulus standar KKM dari sebelum diberi tindakan hingga setelah tindakan. Jumlah siswa yang lulus standar KKM sebelum diberi tindakan 17 siswa atau 53,1\% dan setelah diberi tindakan pada siklus I sebanyak 22 siswa atau $68,7 \%$. Pada siklus II, jumlah siswa yang lulus standar KKM sebanyak 28 siswa atau $87,5 \%$.

Saran

Berdasarkan kesimpulan dapat dikemukakan saran bagi guru bahasa Inggris untuk selalu berupaya meningkatkan perolehan kosakata bahasa Inggris siswa, karena penguasaan kosakata bahasa Inggris adalah salah satu faktor utama dalam meningkatkan pemahaman bacaan berbahasa Inggris. Strategi VSS dapat digunakan sebagai alternatif dalam meningkatkan perolehan kosakata bahasa Inggris siswa. Hal tersebut dinilai mampu meningkatkan perolehan kosakata bahasa Inggris secara mandiri.

\section{Daftar Pustaka}

Nawab. (2012). Is it the way to teach language the way we teach language? English language teaching in rural Pakistan. Academic Research International. Vol 2,2. 696-704.

Badan Standar Nasional Pendidikan. (2006). Standar kompetensi dan kom- 
petensi dasar tingkat SMP/MTs dan SMPLB. Jakarta: BSNP.

Munkova, D., et al. (2014). Personal need for structure and reading comprehension in a foreign language. Studia Psychologica. 56,3. 199-214

Haggard, M. (1982). The vocabulary selfcollection strategy: An active approach to word learning. Journal of Reading. 26,3. 203-207.

Harmon, J.M., Wood, K.D., Kisser, K. (Januari 2009). Promoting vocabulary learning with interactive word wall. Middle School Journal. 40,3. 58-63.

Isriani Hardini, I., \& Puspitasari, D. (2012). Strategi pembelajaran terpadu (teori, konsep, dan implementasi). Yogyakarta: Familia.

Kemmis, S. \& Taggart, R.M. (1988). The action research planner. Victoria: Deakin University.

Linse, C. T. \& Nunan, D. (2006). Practical English language teaching. Boston: McGraw Hill.

Sanjaya, W. (2011). Kurikulum dan pembelajaran. Jakarta: Kencana.

Yopp, H.K., Yopp, R.H., \& Bishop, A. (2009). Vocabulary instruction for academic success. Huntington Beach, CA: Shell Education. 